OPEN ACCESS

UNIVERSITY OF THE

WEST of SCOTLAND

UWS Academic Portal

\title{
Islamic religion and death metal music in Indonesia
}

James, Kieran; Walsh, Rex John

Published in:

Journal of Popular Music Studies

DOI:

10.1525/jpms.2018.200007

Published: 30/09/2018

Document Version

Peer reviewed version

Link to publication on the UWS Academic Portal

Citation for published version (APA):

James, K., \& Walsh, R. J. (2018). Islamic religion and death metal music in Indonesia. Journal of Popular Music Studies, 30(3), 129-152. https://doi.org/10.1525/jpms.2018.200007

\section{General rights}

Copyright and moral rights for the publications made accessible in the UWS Academic Portal are retained by the authors and/or other copyright owners and it is a condition of accessing publications that users recognise and abide by the legal requirements associated with these rights.

Take down policy

If you believe that this document breaches copyright please contact pure@uws.ac.uk providing details, and we will remove access to the work immediately and investigate your claim. 
"This is the peer reviewed version of the following article: James, K. and Walsh, R. (2018) Islamic religion and death metal music in Indonesia - Part 1. Journal of Popular Music Studies. Vol. 30(3), pp. XX which has been published in final form at [Link to final article using the DOI]. This article may be used for non-commercial purposes in accordance with Wiley Terms and Conditions for Use of Self-Archived Versions."

https://authorservices.wiley.com/author-resources/Journal-Authors/licensing/self-archiving.html

To be completed on publication. 


\title{
Islamic Religion and Death Metal Music in Indonesia: Part 1
}

\begin{abstract}
The Bandung (Indonesia) Death Metal scene is known for its secular orientation whereby religion and religious belief are viewed as private matters which should be restricted to the private realm. Metalheads may freely go the mosque or church but in their capacities as private citizens only; religious identification and activity is not permitted to infringe upon the scene's dominant discourses and practices. We look at the differences in discourses and practices between the Jakarta-based One Finger Movement (Islamic) bands and the Bandung secular scene and we consider the response of Indonesian metalheads to the Islamic bands. We also investigate the dominant discourses and practices of the secular Bandung scene and highlight the commitment of its members as an outgrowth of the Sundanese pride movement and as part of the broader historical rivalry between Sundanese Bandung and the capital-city Jakarta. We also look at the history and perspective of the band Saffar and why its Bandung scene location is significant in explaining its members' attitudes towards the Islamic bands.
\end{abstract}

Keywords: Bandung; Death Metal music; Heavy Metal music; Indonesia; Indonesian Islam; Indonesian popular music; One Finger Movement; Jakarta. 


\section{Islamic Religion and Death Metal Music in Indonesia - Part 1}

\section{Introduction}

\section{General Introduction}

The Indonesian Heavy Metal scene has been well-documented by scholars (including most notably Baulch (2003, 2007), Wallach (2008, 2011), and James and Walsh (2015)); the scene is variegated, longstanding and deeply rooted; and the scene, while largely secular, contains religious elements that have heretofore been understudied. This article represents one of our early attempts to begin to remedy this latter deficiency. It is written from our broadly sympathetic perspective and from a somewhat Christian perspective (since the firstmentioned author has a history of sustained interest in Christian Metal and self-identifies as a Christian). This article is not the place to find satanic, pagan or atheistic critiques of Islamic Metal although obviously we might find such articles emerging in future discourse.

The Bandung (Indonesia) scene has become extremely successful (if not hegemonic then at least a leading force) throughout Indonesia and the region and its set of dominant discourses and practices have long ago been set in stone or reified. This scene made it to Europe in 2015 when Jasad played at Obscene Extreme Fest in Czech Republic and Bloodstock Open Air in England; and Burgerkill also played European festivals during that northern summer. The Bandung Death Metal icons from the first day of our field-work (24 February 2011) are essentially the same people today, although a few modern-metal and metalcore bands (especially Revenge the Fate) have rapidly shot to popularity. The Bandung scene is known for its secular orientation whereby religion and religious belief are viewed as private matters which should be restricted to the private realm. ${ }^{1}$ Metalheads may freely go the

\footnotetext{
${ }^{1}$ As van Zanten (2007, p. 1) makes clear, Indonesia is the country with the largest number of Muslims (around 228 million) but it is not an Islamic state. There are no special privileges for adherents to any particular religion. However, ID cards make mandatory the inclusion of the card-holder's religion and the listed religion must come
} 
mosque or church but in their capacities as private citizens only; religious identification and activity is not permitted to infringe upon the scene’s “discourses and practices” (Kahn-Harris, 2004, pp. 100, 105, 107).

We look at the differences in dominant discourses and practices between One Finger Movement (Metal Satu Jari) (Jakarta-based Islamic) bands and the Bandung secular Death Metal scene. We also study Bandung Death Metal band Saffar which was known for its Islamic lyrics on its debut full-length studio album Mandatory El Arshy (Extreme Souls Production (ESP), 2013) but which is now in something of a limbo due to the departure of vocalist and lyricist Parjo. We also consider Saffar's positioning of itself as a "secular” band with Islamic Religion and Anti-Zionist lyrical themes rather than as an Islamic band per se. This dichotomy can be best explained perhaps by the phrase "a band of Muslims rather than a Muslim band” although "band of Muslims” applies to many acts without religious lyrics.

The topic of religion and metal music in Indonesia is not perceived as something which most Indonesian metalheads want to focus on or discuss. ${ }^{2}$ This has made data collection difficult despite our extensive contacts within the Indonesian scene. The only partial (not total) exception to this would be Islamic metal bands Purgatory, Tengkorak, and Kodusa. The interview responses of guitarist Samier ${ }^{3}$ of Tengkorak will be studied in depth later in this article. Most Indonesian metalheads think that religion is a private matter to be practised in private and that a person's faith (or lack of one) is irrelevant when she / he participates in the metal scene. In some ways this is a reaction to the fact that Islamic belief and practice is actually a very public and hegemonic aspect of Indonesian life (albeit not to the extent of the

from an approved list of six (Islam, Protestantism, Catholicism, Hinduism, Buddhism, and Confucianism). The main religions are Islam 87.2\%, Protestantism 7.0\%, and Roman Catholicism 2.9\% (i.e. Christianity 9.9\%).

2 This was pointed out to me (the first-mentioned author) directly one night in a Bandung (West Java) pub in July 2016 by the female Demons Damn vocalist Popo Puji Apriantikasari. Also present were her husband Bobby Rock (ex-vocalist of Bleeding Corpse / current vocalist of Turbidity); Arief Budiman (metal scene identity and Persib Bandung Football Club employee); and one member of the band Auticed.

${ }^{3}$ The alternate spelling Samir is also sometimes seen. Samier is the version of the name listed on Metal Archives’ Tengkorak page and Samier's friend Dimas Bramantyo, from Surabaya Power Metal band Valerian, says that Samier is the preferred or usual spelling (source: online conversation with author, 30 April 2018). 
Middle East). Metalheads want a safe place to pursue their subcultural interests and practices free from outside influences from the broader society. As Wallach et al. (2011, p. 17, emphasis added) write: "metal comes to function as a unique and appealing vehicle of youth identities ... not burdened by religious ... pressure”. Local metalheads also want to fight the perception they have that westerners find Indonesian metal interesting because it (Indonesia) is a Muslim country. ${ }^{4}$ They justifiably feel that this reductionism oversimplifies the complex influences which metal musicians have and the complex set of meanings, discourse, and practices which constitute the Indonesian scenes. The opposition of secular metalheads, especially in the provincial city of Bandung (located 147 kilometres ${ }^{5}$ south-east of Jakarta), to the One Finger Movement springs from similar ideas and ideals which hold that religion should be relegated to the private realm and to one's life outside of the metal scene.

\section{Christian and Islamic Metal}

Christian and Islamic Metal are frequently criticized, by secular metalheads, on the tenuous basis that their proponents are "really" and first and foremost religious evangelists and hence they are not "really" "sincere" metalheads who love and play metal-music for its own sake. According to this criticism, these people are just cynically "using” the metal scene to promote their own private (religious) beliefs and agendas and to convert people. Quite clearly this is a strawman argument in that it fails to reflect the complexity of Christian and Islamic Metal discourses and practices and in particular how individuals in these scenes mix, harmonize, balance, sort, and classify their religious- and metal-oriented behaviours so that the resultant mix of discourses and practices reflects closely enough their own values and preferences. Indonesian metalheads' reactions to the Islamic bands Purgatory and Tengkorak tend to vary from strong support to real indifference to pretend indifference to directly expressed dislike.

\footnotetext{
${ }^{4}$ This point was also made to me directly by Popo on the same evening (see earlier footnote).

${ }^{5}$ This is the distance by road according to Google Maps. The distance by air is 115 kilometres.
} 
The latter would usually be expressed quietly one-to-one in private conversations with trusted others. The percentage of metalheads in each category on the spectrum ranging from strong support to dislike is almost impossible to ascertain with any precision due to the disinterest or antipathy or nervousness which the topic of religion generates.

No-one could argue that Samier of Tengkorak, for example, does not genuinely love metal-music and he certainly enjoys being part of the Surabaya scene. He is aged around 40to 45-years-old and is now a senior statesman of the metal scene in Surabaya. He has strong relationships, for example, with the members of Surabaya Power Metal band Valerian. He is widely respected by younger musicians and metalheads and this feel-good factor has allowed Tengkorak, in recent years and at least in Surabaya (all the other band members are based in Jakarta), to turn some negative opinions about the band into positive opinions. Samier does not to go to the other extreme either; he sometimes wants to bring our interview away from discussion of religion to discussion of actual music. On the other hand, the guitarist of a wellknown Jakarta Power Metal band has told the author that he does not want to attend social meetings where any One Finger Movement people might be present. This guitarist sees the One Finger Movement partly in terms of its anti-Zionist politics and, as an IndonesianChinese, he is wary of any racialist aspects of the One Finger Movement's position given the anti-Chinese riots which occurred in Jakarta in the nineties. He also has an interest in Satanism, Chinese mythology, the occult, and ghosts and he does not view kindly the perceived preachiness and moralism of the Islamic bands. The arms-length atmosphere in Jakarta remains different from the collegial and fraternal mood in Surabaya.

\section{Research Questions}

This article poses and attempts to satisfactorily answer the following research questions: 
(a) What are the histories, motivations, and worldviews of the Indonesian Islamic metal bands which made up the One Finger Movement?

(b) What has been the response of Indonesian metalheads to the Islamic bands?

(c) What are the dominant discourses and practices of the secular Bandung Death Metal scene and what explains the commitment of its members?

(d) What is the history and perspective of the band Saffar and why is Bandung scene location significant in explaining its members' attitudes towards the Islamic bands?

(e) Why are Saffar's members keen to present themselves as a "band of Muslims" rather than as a "Muslim band”?

The present article is structured as follows: Section 2 provides background information about the One Finger Movement; Section 3 provides analysis of our interview with the Tengkorak (One Finger Movement band) guitarist Samier; Section 4 analyses the Bandung secular Death Metal scene and the bands Jihad and Saffar; while Section 5 concludes.

\section{Background - One Finger Movement}

The One Finger Movement (Anonymous, 2015; Saefullah, 2017, pp. 270-1, 273-4) was a community organization or collective of bands, fans, and gigs, which had an ethos of being pro-Islamic and anti-Zionist rather than being secular in the spirit of the Bandung scene and most overseas scenes (Anonymous, 2015). It can be viewed as roughly equivalent to the Christian Metal scenes of the west and of South America but only in that it aims to spiritually nourish and encourage religious people who already have an active interest in metal music. ${ }^{6}$ This is also the way that Marcus Moberg (2011, pp. 46, 48) characterizes the Finnish Christian Metal scene (see also Bossius, 2011, p. 59). Moberg (2011, p. 46) writes that the

\footnotetext{
${ }^{6}$ One difference between Christian Metal and One Finger Movement may be the view sometimes expressed in the latter that Islamic Metal is a temporary but imperfect solution (a transitional stage) before ultimately people realise that metal-music in its entirety is not good and give it up (Kurniawan, $\mathrm{n} / \mathrm{d}$ ). This view may not be shared by all the movement's spokespersons and we don't pursue it further.
} 
scene provides a "distinct cultural space” where people "can share their passion for metal ... with like-minded people who ... share their Christian beliefs”. Evangelism in the Christian sense has never been the primary purpose of the One Finger Movement (which contradicts the earlier statement made by Weinstein (2000, p. 54) with respect to Christian Metal or at least with respect to Stryper) because Indonesia is a Muslim-majority nation and the emphasis has been on inspiring Muslims to deepen and strengthen their faith and bring back to faith those who have been slack or who have experimented with western lifestyles including both liberal-democratic and left-wing ideals (Anonymous, 2015; Saefullah, 2017). There is no concept identical to being "born again” within Islam. Similarly, the Punk Muslim Surabaya collective aims to be as follows: “a mediation, an intermediary, a channel, for anyone within the punk subculture that wants to try to (re)learn their religion and begin to adopt Islamic values for their everyday lives” (Yani, 2016, p. 6, cited in Saefullah, 2017, p. 277). The One Finger Movement was based mainly in Jakarta and it also had some influence in Malang (East Java) and Medan (Sumatra). Jason Hutagalung ${ }^{7}$, an Australian-based Indonesian music promoter and tattoo-artist, estimated that the One Finger Movement comprised about 20\% of the Jakarta scene as at January 2011.

The movement had its supporters and opponents, the main figures for each camp being Ombat $^{8}$ and Samier of Tengkorak for the Islamic bands and Doni "Iblis" Herdaru (the vocalist of Funeral Inception) for the Satanic or hell-raiser bands. ${ }^{9}$ The academic researcher Indra HS (Saefullah) says that this specific skirmish, but only so far as it concerned Doni

\footnotetext{
${ }^{7}$ Ethnically Jason is Batak from North Sumatra. However, he approached the One Finger Movement from the secular or hell-raiser viewpoint rather than from a Christian viewpoint. He has been based in Australia for 20 years and has spent time in Bali and his essentially secular attitude reflects his time spent in these two locations operating primarily as a music promoter and tattoo-artist. There is no way of knowing for certain what Jason's attitude towards One Finger Movement would have been had he been from a Muslim-majority Indonesian ethnic group (such as Javanese or Sundanese). His name became better known when his company Xenophobic Records arranged for Bandung band Burgerkill and Jogjakarta band Death Vomit aka Devo to tour Australia (legally with proper visas and all requisite fees being paid). The Devo tour took place in September 2010.

${ }^{8}$ An interview with Ombat (with English subtitles) appears on the Global Metal DVD (2008) (directed by Scot McFadyen and Sam Dunn).

${ }^{9}$ There seems to be a similar gap or tension in France between committed French-Muslim rappers and those audience members and critics who prefer a more secular outlook (Molinero, 2011, p. 123).
} 
Iblis, has since been resolved. ${ }^{10}$ The movement was named after the one finger sign (meaning "one God") used by its proponents and supporters in place of the generally accepted worldwide devil's horns symbol which they viewed as unacceptable (Saefullah, 2017, p. 270). This one finger sign involves metalheads touching each other's extended forefingers tip-to-tip. The major bands of the One Finger Movement were Purgatory (formed 1991); Tengkorak (formed 1993); and Kodusa (formed 1998); and the movement was also associated with Al Azhar Mosque in Jakarta attended by Ombat (Anonymous, 2015). (All three of these bands are Jakarta-based; although Tengkorak guitarist Samier lives in Surabaya, East Java province.) The movement as a whole can be traced back to 1999-2000 (ibid.). While the name of the movement may have outlived its usefulness, all three bands remain active today and continue with the same Islamic ethos and worldview.

Jason says that the consensus among secular metalheads was not to give the One Finger Movement any attention or air to breathe. The following conversation with Jason introduces the context and the main players:

“Author: How many bands were involved in this skirmish or disagreement?

Jason: There are only a handful of bands involved [in the skirmish] - Funeral Inception leader Doni Iblis and, on the Muslim side, Tengkorak, meaning “skull”.

Author: What does this Muslim band sing about?

Jason: The band preaches about going to the mosque and praying. They are connected to Islamic [Defenders] Front [Front Pembela Islam, FPI]. These people want the country to become a Muslim country; they have their own publication, magazine.

Author: What percentage of the scene do you think is fundamentalist and where is it strongest?

Jason: About 20\% of hard-core metal people [would support One Finger Movement] mostly in Jakarta, Malang and Medan. We had an agreement to ignore them and not give them publicity. We have not heard from them much but they are around in the Indo metal community" [author’s first interview with Jason Hutagalung, 11 January 2011].

\footnotetext{
${ }^{10}$ Source: Comments made by Indra HS on an earlier version of this article, 2018.
} 
Jason refers here to FPI (Front Pembela Islam or in English Islamic Defenders' Front), a militant Islamist organization which has created nervousness and fear in the minds of some secular metalheads. Further discussion about FPI is beyond the scope of this article. ${ }^{11}$

Saefullah (2017, pp. 273-4) argues that support for One Finger Movement has declined significantly in recent years. This may be true but it seems that he bases this observation on the low crowd attendance and lack of enthusiasm for moshing at Tengkorak's Jakcloth Festival 2016 appearance. Strangely, Ombat urged this crowd to pray for the disbandment of Tengkorak (ibid., p. 273). However, in our online interview with Kodusa on 27 November 2015, the band proclaimed that not only the term but the movement as well was still thriving.

\section{Interview with Samier from Tengkorak}

\section{Introduction}

I (the first-mentioned author) spent three weeks in Surabaya during two 2014 field-trips (January 2014 and December 2014) where I was hosted by Dimas Bramantyo, the guitarist of local Power Metal ${ }^{12}$ band Valerian. This hosting allowed me to meet and interview Samier from Tengkorak band. I visited Surabaya radio station Colors Radio 87.8FM, where Samier works; watched Samier play guitar at an Anthrax tribute night hosted by the associated Colors Pub (address: Jl. Sumatera No 81; Surabaya 60281); and interviewed Samier about Tengkorak and his other band, the new Surabaya-based political grindcore act G.A.S.

\section{Samier Interview (Tengkorak)}

The first-mentioned author asked Tengkorak guitarist Samier to explain the vision and philosophy of his band Tengkorak. Samier answered as follows:

\footnotetext{
${ }^{11}$ FPI has a detailed Wikipedia entry and interested readers can refer there for more information. FPI page on Wikipedia: https://en.wikipedia.org/wiki/Islamic_Defenders_Front [accessed 29 January 2018].

12 The reference here is to the genre Power Metal and not to the Surabaya-based band called Power Metal which was involved in a dispute with the American Thrash Metal act Testament at Kukar Rockin' Fest 2014. For readers interested in this dispute Testament's apology can be read at the following link: http://www.testamentlegions.com/site/2014/03/12/statement-regarding-kukar-rockin-fest-2014/ [accessed 1 May 2015].
} 
"Samier: It comes from our [personal] philosophy itself. We have faith in Allah, we believe Islam; it's a good religion, not a terrorist. We should tell about the truth. A lot of kids in Indonesia, especially in Jakarta, at that time were starting to doubt their beliefs so we counter that. A lot of bands say they don't believe in God; some of them are fake [hypocritical] you know. If they don't believe [in] God they don't [i.e. can't, theologically speaking] believe [in] Satan. If they believe Satan but don't believe God, it's ridiculous, man! So we tell the truth. We want the kids who watch us to continue to believe their religion. Although they like metal they should not accept the lifestyle” [source: author’s interview with Samier, 26 January 2014].

Samier asks why God cannot be discussed in the metal scene whereas Satan can be discussed, claiming that this is "ridiculous”. As Samier argues, if you do not accept and honour God how can you accept and honour Satan since they are both key elements of Christian and Islamic theology with God having a nobler character and also being more powerful (Häger, 2011, p. 18)? Satan is a created being (a fallen angel) whereas God is Eternal (Robbins, 2014, p. 88). The situation of accepting Satan but not God in your discourses and practices is labelled as “ridiculous” by Samier presumably because these metal scene discourses and practices run contrary to Samier's previously-held worldview (held since early childhood) that God is greater, mightier, and worthier than Satan. The assumption is that, for most Muslims in Indonesia, they were socialized into Islamic religion at a very young age by parents; nuclear and extended family; mosque; school; and community; and this socialization for most people would predate chronologically their first involvement in the metal scene. This might not be true in all cases but, in the Indonesian context, it is probably a reasonable assumption. The issue is then crafted in terms of where one's primary loyal and identification should lie. Islamic devotion to God / Allah should take priority in one’s heart and actions over one's involvement in metal scene discourses and practices according to Samier. As we shall soon see, this assumption implies for Samier (but not for those who want to keep the scene secular and / or satanic) that it is right and natural that Islam can "enter” legitimately into the metal world; and it should enter from the viewpoint that it is deeper and superior.

That Islam is worthier of deeper devotion than metal scene discourses and practices is uncritically accepted by Samier and this assumption or conclusion has a complex relationship 
with the other assumption that most Indonesians' socialization into Islam occurs chronologically prior to their socialization in the metal scene. Samier couches this connection not only in terms of the need for respect for and devotion to your earliest religious teachers; but also the presumption that Indonesian society has "got it right" by socializing young children into Islamic belief and practices early on. Samier expressed privately his fear that Islam may become less important in Indonesia in the future so that it will no longer play such a vital role in most children's earliest socialization experiences as it does today. He cites the declining role of the Church and Christian belief in European countries (Bossius et al., 2011, p. 7; Moberg, 2011, pp. 33, 39-44, 2012, p. 121) as providing a rational basis for his fears but there is the unstated implication left hanging in the air that this decline in the west might be due to Christianity being false or incomplete whereas Islam is true.

The author's interview with Samier, after a promising start, then appears to get dragged down by the usual clichéd discussion of which aspects of metal scene discourses and practices are acceptable to Samier and which are not. This list of acceptable and unacceptable practices became the humorous highlight of the Swedish documentary-making brother-andsister Resborn team's interview with Ombat of Tengkorak in their coffee-table book Labour of Love \& Hate (2012, pp. 127-30) where the terms halal and haram are used in jokey fashion (at least by the Resborns) to classify scene practices. ${ }^{13}$ However, we note here in the interview responses, that Samier does add some important content to the discussion (before it is again dragged down into a list of dos and don'ts by the present author!)

"Author: What are the things wrong with metal lifestyle and what things are OK?

Samier: A lot of metal fans here say that you are not metal if you are not drunk; you are not metal if you are not tattooed; it happens over the years. If you live in Indo you don't have to take that lifestyle if you like metal. You have your own lifestyle. As a child you studied your religion, you prayed, it was like that. If you like metal you should not leave what you believe. If you believe it is not correlated with your music. Music is just entertainment. If you like horror

\footnotetext{
13 The Tengkorak interview in Labour of Love \& Hate does not actually feature any of the actual words of Ombat. It involves a telephone conversation with Ombat's brother Ucuk where Ombat's views are explained by his brother (which simultaneously results in an English version of Ombat's views being created by Ucuk).
} 
movie it does not mean you are a killer or something like that. Don't adopt the western lifestyle. If the lifestyle doesn't match with your religion don't take it.

Author: What about black tee-shirt and long hair?

Samier: It's OK for me; it's not OK for some. In the end we realize the music has power to state our message. If people have a bad message in their music the metal fans think it's OK. Why then is the good music [i.e. the message of the good music] not OK? In Indonesia it's different to other [western] nations, you still have religion” [source: author's interview with Samier, 26 January 2014].

In the first response Samier first notes that the worldview that a certain image and set of subcultural practices are deemed part and parcel of taking on a metalhead identity has become a part of the metal scene culture in Indonesia and these influences have slowly accumulated and crystallized over the years. Here we see Samier refer again to the importance of the assumption that one's early childhood socialization into religion occurred chronologically prior to one's becoming part of the metal scene. Then we get the injunction from Samier which relies upon this crucial assumption: “If you live in Indo you don’t have to take that lifestyle if you like metal. You have your own lifestyle”. This injunction or instruction is straight-forward in theory but in practice it is sure to be complicated to apply. Clearly someone rejecting the moral worth of this injunction not to "take the metal lifestyle" might then have issues with the entire philosophy and purpose of Samier. It would depend upon which aspects of the lifestyle are being referred to and to what extent the metalhead views these aspects as being important compared to that person's own religious beliefs. It is easy to be caught up in the never-ending cycle of arguing about the dos and don'ts.

Samier then puts forward his belief or goal that music should be seen only as "entertainment” ${ }^{14}$ (Samier’s word) which ignores the fact that metal-music to many of its adherents has meanings and values which go beyond "mere entertainment" as indicated by most metalheads' loyalty to their preferred bands and disdain for "superficial” pop-music (Avelar, 2011, p. 137; Greene, 2011, p. 117; Wallach et al., 2011, pp. 8, 13). Samier says:

\footnotetext{
${ }^{14}$ Consistent with Samier, Cronos of Venom is quoted as saying that "rock and roll” and presumably his band should be seen as "basically entertainment” and nothing more (cited in Olson, 2008, p. 14).
} 
“As a child you studied your religion, you prayed, it was like that. If you like metal you should not leave what you believe. If you believe it is not correlated with your music [because music should only be viewed as entertainment]”. Lastly, the injunction is stated in more direct form: “If the lifestyle doesn't match with your religion don’t take it”. As mentioned, we can conclude that the message is to not let metal scene practices enter into the deepest parts of your loyalties or values system without them being interrogated first (and probably not even then). It is not at all the case that Samier hopes that you will view metalmusic as something useless or unimportant since Samier's lifelong devotion and commitment to metal-music would seem to run contrary to that presumption. It is about the ordering of priorities and what you give your heart to (which is a very religious worldview). This is not to say that this worldview is impossible since in our many daily interactions we habitually bring some friends and contacts into our inner circle and keep others outside of that. The injunction is to treat metal scene discourses and practices in the same way as we treat individuals.

Samier then refers to an oft-repeated theme when metal ethics are debated: metal lyrics about serial-killing are rarely acted out in practice and he uses this example to reinforce his point that we do not need to take literally or take into our heart all metal scene practices. However, there is a tension here with his earlier stated view that even trivial practices (alcohol and tattoos are the examples he mentions but devil's horns in pictures and 666 and inverted cross signs in band logos and on website pages could be added), by their very repetition, attain a deeper level of significance over time as they crystallize and become regarded as synonymous with metal. Within Samier's worldview we may just have to live with such existential tension. The tension remains of being torn in various directions by your varied influences, which is sometimes referred to metaphorically, within Christian Metal 
circles, as being too worldly for the church and too holy for the world. ${ }^{15}$ Why should there be an easy way out? The easy way would be simply to leave the metal scene altogether, a path chosen by Niza, the female hijab-wearing Surabaya-based ex-vocalist for Death Metal bands Climaxeth and Osiris. This path is not directly encouraged (or discouraged) by Samier since it is not a path which he has chosen. If we look at the case of Niza, her bandmates and other metal scene members were saddened by her departure from the Surabaya and Sidoarjo metal scenes around 2014. One of these people was the Osiris bassist Dwi Yudha who did some interpretation work for the author in Madura and Sidoarjo. The fact that Niza has been missed suggests that, in hindsight, committedly religious metalheads are able to contribute something significant and positive to a secular scene during periods of sustained involvement.

In interview with the Resborns, Purgatory band members recall the Napalm Death concert in Jakarta when the frontman said: "Religion is a myth - it only creates conflicts \& bloodshed bla bla bla..." and the Indonesian audience responded: "Yeeeeeaaaaaahh" (cited in Resborn and Resborn, 2012, p. 124). Purgatory admits to being “stunned” as these people are meant to be a Muslim audience and most would probably confess to Muslim identity in nonmetal contexts (such as Indonesian identity cards where one of six approved religions must be stated). Clearly it is conflicted and confused metal audiences like these, which treat the utterances of western metal musicians with the utmost respect as part of receiving "gestur[es] [from] elsewhere” (Baulch, 2003, 2007), which Samier wishes to bring back to committed religious faith and practice (and Samier says, speaking in his dual capacity as a Muslim and a metalhead, that "we realize the music has power to state our message"). As the radical theologian Jeffrey W. Robbins (2014, p. 88) writes about St. Augustine: "It is knowledge of God that anchors self-knowledge [from the perspective of the Abrahamic religions]”.

\footnotetext{
15 The new negative perception towards Christian metalheads' long hair and other lifestyle choices at Livets Ord (Word of Life) congregation in Uppsala, Sweden around 1992-1993 is recounted by Häger (2011, pp. 18-24).
} 
The positivity and good values and ethics of the American hardcore scene (Agnostic Front, Biohazard, Madball, Sick of it All, etc.) was perhaps partially a collective response to the increasing trend towards dark (Moberg, 2012, pp. 114, 116, 122-4) and evil (Phillipov, 2011, pp. 153-4, 157-8, 160, 162) metalhead discourse and practices which occurred in Europe and North America around 1992-1994 with the rise of Norwegian Black Metal (with its church-burnings, blasphemies, and murders) (Bennett, 2009; Bossius et al., 2011, p. 8; Granholm, 2011, p. 529; Hagen, 2011, pp. 180-1; James and Tolliday, 2009, p. 151; KahnHarris, 2011, pp. 202-3, 215; Mørk, 2011, pp. 124-5; Moynihan and Søderlind, 2003; Mudrian, 2009; Phillipov, 2011, pp. 152-6) and Floridian Death Metal (with its graphic firstperson lyrics of rape, torture, murder, and mutilation) (Dick, 2009; James, 2009; James and Tolliday, 2009, p. 151; Kahn-Harris, 2007, pp. 36, 43, 76; McIver, 2014; Phillipov, 2006; Purcell, 2003, pp. 43-4). Norwegian Black Metal took literally and to its ultimate "logical” (Phillipov, 2011, p. 152) conclusion (or illogical conclusion) what the earlier Heavy Metal and Thrash Metal scenes had managed to largely relegate to the symbolic realm.

Towards the end of the interview the author asked Samier what he thought of the global hardcore culture (as opposed to the global metal scene culture) expecting him to praise it for its positivity and good values. It is good that hardcore culture emphasizes family and respect but Samier says that the source of these good values is ultimately religion rather than hardcore. Therefore, inspiration should be sought in the Al-Quran rather than in hardcore lyrics despite their positivity. (This is literally what Samier said to the Muslim music journalist Wendi Putranto of Rolling Stone magazine.) This statement suggests Samier believes that hardcore and metal scenes can only mirror and replicate positive things which existed in other contexts first and especially in religious contexts. We can read Samier's response here:

"Author: What do you think of the culture of hardcore genre? 
Samier: I think it's good because if we learn religion you will find that you should respect family, parents, mother, sister, etc. All the good things come from our religion, your religion ...I think a hardcore band should say about religion. Our culture came from religion. If they don't say that a lot of people think hardcore is a religion. I read that it says metal has become a religion. Wendi of Rolling Stone magazine said hardcore lyrics are inspiring. Wendi is a Muslim. I told him that if you want inspiration you should read Al-Quran” [source: interview with Samier, 26 January 2014].

To conclude this section, we can say that Samier is concerned about the lack of devotion to Islam and the abandoning of religious fervour and sincerity by some young people after they begin their participation in the metal scene. ${ }^{16}$ Samier's goal is to counter this perceived negative influence so that metalheads may enjoy their participation in the scene (as Samier does by releasing albums and touring with Tengkorak and his grindcore band G.A.S.; playing guitar at an Anthrax tribute night held at Colors Pub; and by working at Colors 87.8FM radio station) whilst keeping their earlier religious fervour and devotion intact.

\section{The Bandung Death Metal Scene and Saffar}

\section{Bandung Death Metal scene}

Keith Kahn-Harris (2004, p. 99) writes that: "Distinct scenes have developed around particular genres on regional, national and global scales, yet they share enough musically and institutionally so that we are able to talk of them as quasi-autonomous parts of a wider global extreme metal scene”. The Bandung Death Metal scene ${ }^{17}$ is known for its size; dedication and commitment ${ }^{18}$ (to the Death Metal sub-genre in particular (James and Walsh, 2015)); extreme self-confidence; professionalism; hierarchical nature; strong and cohesive networks of merchandise shops, recording studios, record labels, artists, and tattoo stores; large number

\footnotetext{
${ }^{16}$ Music scholar Indra HS disputes Samier's conclusion that metal music causes Indonesian people to lose their earlier religious devotion and he asks what evidence Samier bases his opinion on. In Indra's words: "How does he measure one's devotion to their religion? In his generation (my generation as well), devotion to Islam does not necessarily have to be shown explicitly" (source: Indra's comments on earlier draft of this article, 2018).

${ }^{17}$ Death Metal is the most famous and popular metal sub-genre in Bandung (James and Walsh, 2015); although some modern-metal bands are rising fast. Death Metal and Death Metal people remain hegemonic in the Bandung metal scene in terms of their domination of institutions, discourses, and practices (ibid.).

${ }^{18}$ Regarding the commitment of metalheads to their local scene in Malta see Bell (2011).
} 
of talented and motivated underground musicians; and high levels of organization (Baulch, 2007; James and Walsh, 2015; Prasetyo, 2017; Wallach, 2008). ${ }^{19}$ It is famous for its penetration into spheres of society not yet reached in other parts of Indonesia including popularity of the genre even among primary-school students and widespread familiarity with the names and even the music of the leading local bands (James and Walsh, 2015). It is associated with a lower middle-class / working-class district in the outer-eastern suburbs called Ujung Berung (or informally "Ujungbronx") where most of the foundation bands originated from in the nineties (ibid.). ${ }^{20}$ Addy Gembel, Forgotten vocalist, views the foundation of the Ujung Berung scene as occurring simultaneously with the coming of industrialization to this semi-rural farming and fishing community on Bandung's eastern fringe (and the anger of the music reflected the anxiety which this historical development generated) (source: author's interview with Addy Gembel, 29 November 2012; see also Avelar, 2001, p. 132; Wallach, 2011, p. 92; Wallach et al., 2011, pp. 17, 26, n. 11, p. 30, n. 17, p. 32; Weinstein, 2011, pp. 41, 52, 54).

Ujung Berung bakes in the hot sun but it is chilly in the evenings as the cloud hangs continually over the nearby mountain which casts its eternal shadow upon proceedings below. When we first visited the home of ex-Jasad drummer Dani aka Papap ${ }^{21}$, also used as a rehearsal venue and as home to the Pieces Records label ${ }^{22}$, we entered through a maze of

\footnotetext{
${ }^{19}$ In Bandung long-term members of the senior bands, such as the classic Jasad line-up of Man, Ferly, Yuli, and Dani aka Papap, are now aged around 40-years-old; metalheads older than 50 are non-existent.

20 The legendary Bandung bands were formed in the following years: Jasad 1990; Forgotten 1994; Burgerkill 1995; Injected Sufferage 1995; Disinfected 1997; Jihad 1999; Undergod 2004; and Bleeding Corpse 2006. The famous metal-music festival Bandung Berisik 1 was first held in 1995 (Prasetyo, 2017, p. 196). Prasetyo (2017, p. 198) refers to "Ujung Berung Rebel” (perhaps a little uncharitably) as a "fragmenting group" meaning that this community split itself off to some extent from the Bandung underground as a whole.

${ }^{21}$ Ujung Berung Rebel includes bands from all underground genres. It dates back to the tail-end of the eighties; and is associated with the people who regularly met at Dani aka Papap's house in Ujung Berung (source: personal conversation with Popo, 18 May 2018). Bandung Death Metal Syndicate (BDMS) is the Death Metal sub-grouping or branch of Ujung Berung Rebel and it was formed around 2000-2001 by the following people: 1 Okid of Gugat; 2 Addy Gembel of Forgotten; 3 Amenk of Disinfected; 4 Man of Jasad; 5 Iwan D of the ESP record label; 6 Ferly of Jasad; 7 Papap of Jasad; and 8 maybe Toteng of Forgotten (source: ibid.). Popo; Bobby Rock of Bleeding Corpse (original line-up) and Turbidity (now); Uus Death of Bleeding Corpse; Daniel of Turbidity; and Glenn of Bloodgush can be viewed as being the tail-end of that first pioneer generation.

22 Pieces Records label address: Jl. Rumah Sakit no. 86, Ujung Berung, Bandung 40612.
} 
back alleyways. In many built-up districts there are large numbers of houses which you can only approach on foot or motorcycle via back alleyways as they have no individual street frontages. Metalheads were lounging around outside the back door of Papap’s house, leaning on walls and seated atop motorcycles, while young children were playing football on the grassed communal area behind. Man of Jasad was holding court seated on his motorcycle, and was the centre of attention; while Daniel of Turbidity was making his usual situationhumour jokes (see Figure 1). The very shy and softly-spoken Bloodgush vocalist Glenn was present and in later times he would often be perceived as hiding behind his dreadlocks. Glenn surprised many by being chosen as vocalist (and doing very well at it) by Papap when he formed his new band Dismemberment Torture after being fired or resigning (depending upon who your sources are) from Jasad around the time of his motorcycle accident in mid-2011. The only women usually present at this place are Popo of Demons Damn (the only female Bandung Death Metal vocalist as at 23 May 2018); Maya of Mortality; and Papap’s Javanese wife Amel; and all these women's Ujung Berung credentials are impeccable, with Maya having played alongside her husband in Black / Death band Mortality since 2010 (see Mortality’s page on Metal Archives). On the first day we visited, in February 2011, chickens were walking around freely and washing was draped across front verandas and in every other conceivable position. The mountain and its accompanying grey cloud cover are the scenic backdrop to all these happenings and events.

\section{Insert Figure 1 about here}

We get a situation in Bandung where the leading bands (Burgerkill, Disinfected, and Jasad in particular) have the profile and brand-name recognition value of mainstream rock bands (or approaching such levels) but they still self-identify with the underground scene and play underground festivals (always headlining) for marketing purposes and to retain their hard-won subcultural reputational capital (Bell, 2011, pp. 287-9; Bourdieu, 1979, 1993; 
Kahn-Harris, 2007, pp. 7, 121, 122-7, 128-31, 132-3, 136-7, 138-9, 2011, pp. 210-15; Prasetyo, 2017, p. 190; Thornton, 1995). It is a city where competition is fierce; and festival and gig bills are rigidly controlled and reflect a religiously-observed pecking-order of seniority. Man of Jasad told the first-mentioned author on 24 February 2011 that there were 128 active Death Metal bands in Bandung alone which surely makes Bandung the biggest metal scene in Asia and probably the world. Baulch $(2007$, pp. 115, 156) refers to Bandung as "the heart" of Indonesia's "underground scene" while Wallach (2008, p. 7) writes that Bandung is "home [to] a remarkably disproportionate number of ... musicians”.

The fact that Persib Bandung Football Club built its impressive new 38,000-seater stadium out in the fields at Ujung Berung (opened March 2013) has brought a new level of validation to the metalheads who feel that they were in the district first and paved the way. Now modernity in the form of capitalist national-league football has come to Ujung Berung; and the hooligan supporter element of global football culture reinforces, even in this sphere of life, the earlier underground ethos of the metalheads who were there before it.

We should also note that the Jakarta-Bandung relationship is fraught with tension as reflected in the Sundanese pride ${ }^{23}$ movement and the at times literally deadly football hooliganism between the followers of Persib Bandung ("Viking" firm) and the followers of Persija Jakarta (“Jakmania” firm).

Singapore-based Indonesian Black Metal scene identity Hans Yamin puts forward a critical Jakarta scene viewpoint (within Jakarta the One Finger Movement has never had a majority of bands or followers) about the Bandung scene:

\footnotetext{
${ }^{23}$ Although Bandung and West Java province have a Sundanese (ethnic group) majority (79\% Sundanese in West Java), Java Island as a whole has a Javanese majority. Kinoy of the Bandung band Undergod says that he uses Sundanese lyrics because he felt excluded and marginalized growing up because his Indonesian language skills were poor (source: author's interview with Undergod, 3 April 2012). An interesting moment occurred in our Undergod interview in 2012 when the late music journalist John Yoedi from Balikpapan (East Kalimantan) expressed frustration towards Kinoy because he (John) could not understand Undergod's Sundanese lyrics. Being from an outlying region of Indonesia, John sees the Indonesian language project in primarily positive terms as it unites people spread out over a vast distance with a common tongue. He perceived that Kinoy was failing to understand the usefulness of Indonesian as symbolic national unifier and practical common language.
} 
“There is a reason why Jakarta [scene] looks down on Bandung mate. We're in the know and we know what is going on, we have seen it happen before. And those try-hards can try as hard as they want. They will never be what they want them[selves] to be. [This is the] same reason I stopped supporting the poser Thai scene. [It is the] same festival with same bands always. I mean yes with all due respect it's their money [and] their festival[;] their right to do whatever the $\mathrm{f}^{* * *}$ they want. [B]ecause it's the principles behind it mate that are $\mathrm{f}^{* * *}$ ed up. The reason why same bands play all the time is not because there are no bands. [I]t is because anyone who refuse[s] to suck their dicks will not be given a shot, it means they are outside of the inner circle and they are branded as posers. Now who is the real poser then? Look into the mirror. [A]nd ever since Avaejee's murder ${ }^{24}$ all these act-tough $\mathrm{C}^{* * *}$ s they became complete pussies" [author's online personal conversation with Hans Yamin from Hellucinate band, 8 May 2017, emphasis original, quote used with permission].

Overall, the Indonesian scene must be viewed and understood primarily on a city-by-city basis and not as a large homogenous undifferentiated mass. Understanding tensions between the Bandung and Jakarta scenes and the Bandung and Surabaya scenes are fundamental to understanding the history and contemporary dynamics of Indonesian metal.

\section{Bandung Death Metal scene - secular orientation}

Although Bandung is no less religious than any other Indonesian city, its rich history of arts, culture, and music (Prasetyo, 2017; van Zanten, 2007, p. 11), going back decades ${ }^{25}$, also tends to create an artistic and music community today which feels somewhat empowered and more likely to follow an art-for-art's-sake philosophy (Bossius et al., 2011, p. 4) while also keeping a quiet and regular eye on how to make money from art and music. The art-for-art'ssake philosophy tends to encourage a more professional and secular orientation whereby people expect religion to be relegated to the private sphere. The secular orientation was reinforced and people exerted more effort to defend it after high-profile Death Metal band Forgotten was condemned by Islamic hardliners because of the title of its third-album Tuhan Telah Mati (Rock Records, 2001) (meaning: God is Dead) which was inspired by

\footnotetext{
${ }^{24}$ Hans is referring here to the murder of Thai metal musician Avaejee (from Surrender of Divinity band) who was killed because of a perceived lack of harmony between his satanic metal scene persona and his real-life, a lack of harmony which to some people (including most obviously his murderer but also to Hans) revealed a lack of existential integrity (source: author's online conversation with Hans Yamin, 8 May 2017).

${ }^{25}$ For example, the Bandung-based Bimbo group, one of the oldest popular music groups in Indonesia, was formed as long ago as 1967 (van Zanten, 2007, p. 9). It remained active some 40 years later (ibid.).
} 
Nietzschean philosophy. Addy Gembel (Forgotten vocalist) offered to show the firstmentioned author a threatening text message allegedly sent to him by an FPI member or supporter when we met in Bandung on 29 November 2012.

\section{Introducing Saffar}

One of the more interesting Bandung Death Metal bands is the relatively young Saffar which is in the second-tier or third-tier of the Ujung Berung / ESP hierarchy and is generally widely respected without being a household name outside of the metal underground unlike Burgerkill or Jasad or Forgotten. Saffar was formed in either 2007 (according to Metal Archives) or 2009 (according to Ramon, Saffar bassist, author's first Saffar band interview, 3 April 2012). The first line-up was: Ezot (vocals); Acil (guitar); Faris (bassist from Lumpur); and Andris (drummer from Desire) (source: ibid.). Only band spokesman Acil (pronounced “Ah-chill”) has remained with the band up until today. The band released two demos in 2011 Promo 2011 and You Fear Your Enemy; and participated in a 2011 split-album with one Filipino and two Indonesian bands titled Philippines to Indonesia 4-Way Split of Brutality. ${ }^{26}$

Following this, Saffar released its ten-track debut full-length album Mandatory El Arshy on 9 September 2013 on the high-profile Ujung Berung label ESP (source: band's Metal Archives page). One thousand copies were released of the debut album (ibid.) which is a typical size production run for an established mid-tier band in Bandung. The Mandatory El Arshy line-up was: Parjo (vocals); Acil (guitar); Ramon (bass); and Iyenk (drums) (see Figures 2 and 3). Parjo is pictured wearing a Tengkorak tee-shirt inside the album booklet which certainly nails his Islamic colours to the mast. The band’s lyrical themes are listed on Metal Archives as being Islam Religion and Anti-Zionist.

\section{Insert Figures 2 and 3 about here}

\footnotetext{
26 The other bands involved in this split were Cranial Schism (South Tangerang, Indonesia); Chronology (Central Jakarta, Indonesia); and Last Vigil (Cagayan de Oro City, Philippines) (source: Metal Archives).
} 
Saffar is one of the best examples of the regeneration of the Ujung Berung / Bandung scene from within. Saffar is on many people’s lips as their favourite young or new Bandung band (see author's interview with Dada, ex-Turbidity vocalist, 30 November 2012; author's interview with Addy Gembel of Forgotten, 29 November 2012; comments by Butche of The Cruel in author's interview with Acil from Saffar, 18 July 2016). The Mandatory El Arshy album benefits from a crisp, clear, modern production unlike the muddy production and residual Thrash Metal influences which early Ujung Berung scene albums are known for.

Despite the Saffar band members being very well-connected and good socialisers who pay their dues, the band has not reached the next level of popularity and recognition partly because it tends to do much less marketing and self-promotion compared to other bands; and partly because it has been losing members since the debut album with the only two permanent members from 2014-16 being Acil on guitar and Iyenk on drums. The very talented bassist Ramon was sick for a long time and vocalist Parjo left the band in 2013 to concentrate on helping his parents in their doctors' clinics and his continuing university studies (source: Acil’s interview with the author, 18 July 2016). In 2017 Evan, from Bloodgush and Dismemberment Torture (live band only), became the new Saffar bassist replacing Ramon (source: band's Metal Archives page). The band has no permanent vocalist as at 22 February 2018. Acil comments about Parjo’s situation as follows:

“Acil: Parjo left the band because he wanted to work in his family's doctors' clinic. He will continue what his parents built. Parjo is still continuing his study in college. He also got married and is more focused on work and family. He had a [further] problem because he lives far from Bandung so it was difficult for him to meet with the other band members" [source: Acil's interview with the author, 18 July 2016].

Acil also explained that he does not want to ask Parjo to write lyrics for the next album because "it would be hard for [him] to explain the meaning of the lyrics to the fans [because] only Parjo knows the meaning of his deep [Islamic] lyrics”. 
At our most recent interview with Saffar on 16 May 2018 in Bandung, Acil admitted that, while previously proffered reasons for Parjo's departure are not falsehoods, the main reason is that Parjo now believes that "playing Heavy Metal is not allowed according to his [current] beliefs” but for the other band members playing Heavy Metal is OK (halal). Acil may have been willing to reveal this full information to the researcher this time around because more trust had been established by this later date and also because he was put on the spot by a direct question from the researcher who had been given the information earlier that night by Popo of Demons Damn and he simply wanted Acil to confirm it. However, Acil was adamant when pressed that religion is not the main reason for bassist Ramon's departure. The Bandung Death Metal scene has been leaking members to religious devotion of late with Yudi Zeta of Injected Sufferage quitting the scene also for religious reasons (source: author's personal conversation with Teguh Prasetyo of Interfectorment band, 17 May 2018).

Saffar's inability to break into the next tier of popularity in Bandung (as Gore Infamous and Digging Up have done) may, although this is unproven and unprovable, be due in part to the Islamic religious imagery used in Saffar's lyrics, video-clips, and band merchandise such as valiant Islamic warriors featured on tee-shirts and hoodies.

The album title El Arshy means "the sky" or “coming from the sky” literally in Arabic (source: Acil's interview with the author, 18 July 2016) or colloquially we can say that the reference is to Allah. Acil explained further as follows with interpretation from Indonesian to English being provided by underground punk legend Butche of The Cruel:

"Acil: Coming from the God, you know? The people say: God lives in the sky, God is everywhere. That is why the people say: God is coming from the sky. The sky is the highest place on this planet. We just say "in the sky" meaning God because the sky is the highest place in this planet” [source: Acil’s interview with the author, 18 July 2016].

The use of the English word "mandatory" in front of El Arshy, from a band of non-native English speakers who prefer lyrics in Sundanese and Indonesian, has a vaguely threatening import and Acil did not refer to this word when he explained to the author what the album 
title meant. It probably refers simply to those actions mandatory within Islam, i.e. the five pillars of Islam (van Zanten, 2007, p. 14), but the vaguely threatening nature of the title remains an unresolved issue. Jason Hutagalung has described Saffar as being "too religious" for his tastes (source: author's second interview with Jason, 12 January 2015) whereas Jason confusingly accepts the beer-drinking members of Bandung / Cimahi band Jihad as "not too religious”. ${ }^{27}$ However, showing the subjectivity inherent in Jason's own very personal demarcation line, all of Jihad's members are confessed Muslims; they write lyrics about Islamic theology and philosophy; and their ambition is to go on Hajj pilgrimage to Mecca with their wives and families (the Hajj pilgrimage being the fifth pillar of Islam (van Zanten, 2007, p. 14)) (source: author's interview with Jihad, 30 November 2012). Kancil, vocalist of Jihad, explains the lyrical themes for the second Jihad album Strategi Setan (in English: Satan’s Strategy) (Recluse Production, Singapore, 2005) as follows:

"The lyrics mostly tell about the description of one of the most evil creatures from when he was born until the end of his days. In Islam the evil one can create chaos between humans and is a sign in the Al-Qu'ran for the end of the world. The nickname is 'Dajjal', the real name is 'Samiri', and he has three eyes in his face. We call America or U.S.A. 'Uncle Sam', it means the shortened form of Samiri” [source: author’s interview with Jihad, 30 November 2012].

We note here the closeness between religious commentary and political commentary when comments are being made about the USA being "Uncle Sam" and then the link which is made between Uncle Sam and Samiri.

Jihad band members' adoption of biker culture and dress, in the manner of Motörhead or Saxon or Zakk Wylde, has meant that they do not neatly fit into conventional perceptions about Muslims' look and conduct. This may explain Jason's declaration that Jihad's members, unlike Saffar's, are not, in his opinion, “too religious”. Jason's Xenophobic

\footnotetext{
${ }^{27}$ The band Jihad is originally from Cimahi, Bandung's sister-city to the west (source: author's interview with Jihad, 30 November 2012). However, the band members now self-identify with both Bandung and Cimahi since they were caught up in the Bandung scene orbit as long ago as the nineties and also at that time Cimahi had not yet been officially granted city status by authorities (source: ibid.).
} 
Records was involved in an approved and official overseas reissue of Jihad's third album Origin of the Rebels [sic] Angels (originally released by ESP / Krueger Records, 2013).

Acil has suggested that, with Parjo having departed, Saffar's lyrical themes will expand to include social and historical themes. The reason is that Parjo wrote all the religious lyrics on the debut album and no-one in the current band has the same skill at or perhaps the same interest in writing lyrics on this complex and controversial topic.

Acil's message to the fans on 18 July 2016 was as follows: "We still exist and our new songs will be different to other bands. Our style is always different from other bands" (source: ibid.). With humility and a touch of anxiety he added to the author: "I hope that Saffar will continue to exist” (source: ibid.). Popo, vocalist of Demons Damn, made the following supportive comments: "This is why I do not agree with what they say in other cities that all bands in Bandung follow the style of Jasad. Identity is made through both lyrics and music and Saffar has a unique identity” (source: ibid.). Keeping the unique identity of Saffar without the unique lyrics of Parjo will be a continuing challenge in the years to come. ${ }^{28}$

Saffar has been able to stay under the radar and avoid too much controversy by not publicly aligning itself with the One Finger Movement or the Jakarta scene; by avoiding preaching or the appearance of preaching; by building and maintaining strong relationships with Ujung Berung scene insiders; by having consistently self-identified with the Ujung Berung / Bandung scene since the band's foundation; and by a patient and humble attitude from the band members. In regards to this last point, band spokesman Acil is notoriously soft-spoken and shy and is sometimes seen literally sitting on the ground at the feet of other scene members who are seated on chairs. ${ }^{29}$ As Wallach (2008, pp. 135-6, emphasis added) points out: "paying attention to basic habits of sociality and to fundamental orientations

\footnotetext{
${ }^{28}$ Saffar, with Acil on guitar and vocals, played at the Militan Bersatu show in Bandung on 4 March 2018 (source: gig flyer shared on Facebook by Dani Badar, 18 February 2018). In a Facebook "reply" comment posted on the same date, Dani Badar of Badranaya band confirmed Acil's dual role to the author.

29 This gesture is read as humility in Indonesia.
} 
toward physical space, the presence of others, and the burden of responsibility [are] part of an ethnographic perspective that is frequently missing from [popular music] studies”. When asked about Saffar, Rozi (bassist of Jihad) said: “I don’t know but they are very polite guys”; while Jihad vocalist Kancil added: “very religious” (source: author’s interview with Jihad, 30 November 2012).

Acil has stated to the author that he views himself as a musician and he feels no connection to or affinity with the One Finger Movement which has never had anywhere near the influence or popularity in Bandung as it once had in Jakarta.

"Author: Are you part of One Finger Movement and if not do you support One Finger Movement?

Acil: Personally I try to be natural. I play Death Metal first and foremost and am not oriented towards One Finger Movement” [source: Acil’s interview with the author, 18 July 2016].

Acil was reluctant to discuss religious matters or the One Finger Movement further with the author (even with the competent interpreter Popo Puji Apriantikasari present), preferring to focus instead on the band's music and lyrics; the band's line-up; and the band's future plans. Such an attitude makes perfect sense within the secular Bandung scene.

\section{Conclusion}

\section{General Conclusion}

The Bandung scene is known for its secular orientation whereby religion and religious belief are viewed as private matters which should be restricted to the private realm.

Jihad is a long-standing and widely respected member of the Ujung Berung Death Metal community, although it hails from Cimahi, Bandung's sister-city to the west. As such, it has been allowed to present Islamic philosophical and theological lyrics without in any way being perceived to be a threat to the secular orientation of the Bandung scene. Releasing its second album Strategi Setan on a Singapore-based label as early as 2005 significantly added 
to its subcultural capital within the Bandung scene as part of the mechanism of "gesturing elsewhere” (Baulch, 2003, 2007) and receiving “gestures” from “elsewhere”.

Saffar's members are much younger than Jihad's and appear to be very earnest and dedicated in their religious devotion. Saffar has been accepted by the Bandung scene for the reasons outlined above, i.e. not publicly aligning itself with the One Finger Movement or the Jakarta scene; avoiding preaching or the appearance of preaching; building and maintaining strong relationships with Ujung Berung scene insiders; having consistently self-identified with the Ujung Berung / Bandung scene since the band's foundation; and a patient and humble attitude from the band members. However, arguably, its strong religious lyrics and merchandise have prevented it from both attaining a stable line-up over time (it has been leaking band members since the release of Mandatory El Arshy) and rising up to the next level of success to join other fast-rising bands Digging Up and Gore Infamous.

Overall this article illustrates various diverse ways in which religious metalhead people in Indonesia balance, mix, and harmonizes these diverse and arguably divergent aspects of their personal interests and values. The research is challenging as few Indonesian metalheads prefer to discuss this topic when a myriad of other topics could be talked about instead. We see in this article the divergent ways of perceiving and "doing” religion between the One Finger Movement and bands that are proudly integrated into a well-functioning secular scene such as Jihad and Saffar. We cannot simply equate One Finger Movement attitudes with the Jakarta worldview and the Jihad / Saffar "Muslims in a band" approach with the Bandung spirit. However, we do believe that context is vitally important here. Bandung's long history of arts and culture and its Sundanese heartland status have empowered and given meaning to today's metalheads in a way which does not map easily on to any form of public religiosity; Jihad and Saffar have been hampered rather than helped by their religious foci in their quests to gain wider support. It would be much easier to just be another gore band specializing in 
gore lyrics. We should also note Indonesian tolerance and note that generally the attitude is live-and-let-live and that respect for seniors and hierarchy and dominant scene discourses and practices are vital in maintaining that mundane subcultural capital which Kahn-Harris (2004, 2007) writes about. Mundane subcultural capital, with nods to or gestures towards wild behaviour (e.g. empty beer bottles being strategically placed on tables before band interviews rather than having been drunk previously by the band), may be the best way forward in a country where the influence of the conservative broader society is all pervasive.

\section{Suggestions for Further Research}

East Java (comprising Surabaya, Malang, Kediri, and the rural hinterlands) remains an underresearched area in metal-music studies. Kediri is particularly interesting as this mountainous provincial city has become known around Indonesia for its Technical Death Metal bands inspired by local leaders Killharmonic. Research exploring smaller and younger scenes in more remote places such as Banyuwangi; Blitar; Garut; Jombang; Tasikmalaya; Tulungagun; and Madura Island; and relationships between these scenes and their nearest big-city scene(s) could provide valuable information. We have done some preliminary work on the scene in Madura Island, which had eight underground bands in late-2014 led by Rajam (War Metal) and Sickles (Death Metal). The latter band gained significant exposure and subcultural capital several years ago due to some serious support online coming from Canadian Death Metal expert Andrew Talbot aka Andrew Sick of Sick Reviews. Metal scenes in outlying Indonesian islands, such as Kalimantan, Sulawesi, and beyond are under-researched as is the entire Filipino scene. Obviously, studying new and young Islamic bands and their connections to various scenes and communities should continue to be perceived as important; as well as studying the experiences of Christian musicians playing in "bands of Muslims". 


\section{References}

Anonymous. (2015), “Dakwah anti mainstream: One Finger Movement”, 6 August, available online at: https://sehatisme.com/one-finger-movement-salam-satu-jari/ [accessed 23 February 2018].

Avelar, I. (2001), "Defeated rallies, mournful anthems, and the origins of Brazilian Heavy Metal”, in C. Dunn and C. Perrone (Eds.), Brazilian Popular Music and Globalization (Gainesville, FL: University of Florida Press), pp. 123-135.

Avelar, I. (2011), “Otherwise national: Locality and power in the art of Sepultura”, in J. Wallach, H.M. Berger and P.D. Greene (Eds.), Metal Rules the Globe: Heavy Metal Music around the World (Durham, NC and London: Duke University Press), Chapter 6, pp. 135-158.

Baulch, E. (2003), "Gesturing elsewhere? The identity politics of the Balinese death/thrash metal scene”, Popular Music, Vol. 22, No. 2, pp. 195-215.

Baulch, E. (2007), Making Scenes: Reggae, Punk, and Death Metal in 1990s Bali (Durham, NC: Duke University Press).

Bell, A. (2011), "Metal in a micro island state: An insider's perspective”, in J. Wallach, H.M. Berger and P.D. Greene (Eds.), Metal Rules the Globe: Heavy Metal Music around the World (Durham, NC and London: Duke University Press), Chapter 12, pp. 271-293.

Bennett, J. (2009), “The making of Emperor's In the Nightside Eclipse”, in A. Mudrian (Ed.), Precious Metal: 25 Extreme Metal Masterpieces (Philadelphia, PA: De Capo Press), Chapter 21, pp. 280-291.

Bossius, T. (2011), "Shout to the Lord: Christian worship music as popular culture, church music, and lifestyle”, in T. Bossius, A. Häger and K. Kahn-Harris (Eds.), Religion and Popular Music in Europe: New Expressions of Sacred and Secular Identity (London and New York, NY: I.B. Tauris), Chapter 3, pp. 51-70.

Bossius, T., Häger, A. and Kahn-Harris, K. (2011), "Introduction: Religion and popular music in Europe", in T. Bossius, A. Häger and K. Kahn-Harris (Eds.), Religion and Popular Music in Europe: New Expressions of Sacred and Secular Identity (London and New York, NY: I.B. Tauris), pp. 1-10.

Bourdieu, P. (1979), Distinction: A Social Critique of the Judgement of Taste (London: Routledge).

Bourdieu, P. (1993), The Field of Cultural Production (Oxford: Polity Press).

Dick, C. (2009), “The making of Cannibal Corpse's Tomb of the Mutilated”, in A. Mudrian (Ed.), Precious Metal: 25 Extreme Metal Masterpieces (Philadelphia, PA: De Capo Press), Chapter 12, pp. 142-164.

Granholm, K. (2011), “'Sons of Northern Darkness’: Heathen influences in black metal and neo-folk music”, Numen, Vol. 58, No. 4, pp. 514-544.

Greene, P.D. (2011), “Electronic and affective overdrive: Tropes of transgression in Nepal's heavy metal scene”, in J. Wallach, H.M. Berger and P.D. Greene (Eds.), Metal Rules the Globe: Heavy Metal Music around the World (Durham, NC and London: Duke University Press), Chapter 5, pp. 109-134.

Hagen, R. (2011), “Musical style, ideology, and mythology in Norwegian Black Metal”, in J. Wallach, H.M. Berger and P.D. Greene (Eds.), Metal Rules the Globe: Heavy Metal Music around the World (Durham, NC and London: Duke University Press), Chapter 8, pp. 180-199.

Häger, A. (2011), "Jerusalem in Uppsala: Some accounts of the relationship between a Christian rock group and its congregation”, in T. Bossius, A. Häger and K. Kahn-Harris (Eds.), Religion and Popular Music in Europe: New Expressions of Sacred and Secular Identity (London and New York, NY: I.B. Tauris), Chapter 1, pp. 11-30. 
James, K. (2009), “'From 'The Undead will Feast' to 'The Time to Kill is Now': Frankfurt School and Freudian perspectives on death-metal”, Musicology Australia, Vol. 31, No. 1, 2009, pp. 17-39.

James, K. and Tolliday, C. (2009), "Structural change in the music industry: a Marxist critique of public statements made by members of Metallica during the lawsuit against Napster”, International Journal of Critical Accounting, Vol. 1, Nos. 1-2, pp. 144-176.

James, K. and Walsh, R. (2015), "Bandung Rocks, Cibinong Shakes: Economics and applied ethics within the Indonesian death-metal community", Musicology Australia, Vol. 37, No. 1, pp. 27-46.

Kahn-Harris, K. (2004), "The 'failure' of youth culture: Reflexivity, music and politics in the black metal scene”, European Journal of Cultural Studies, Vol. 7, No. 1, pp. 95-111.

Kahn-Harris, K. (2007), Extreme Metal - Music and Culture on the Edge (London and New York, NY: Berg).

Kahn-Harris, K. (2011), “'You are from Israel and that is enough to hate you forever': Racism, globalization, and play within the global extreme metal scene”, in J. Wallach, H.M. Berger and P.D. Greene (Eds.), Metal Rules the Globe: Heavy Metal Music around the World (Durham, NC and London: Duke University Press), Chapter 9, pp. 200-223.

Kurniawan, A. (n/d), “Komunitas One Finger Movement”, available online at: http://motifnesia.blogspot.co.uk/2015/09/komunitas-one-finger-movement.html [accessed 23 February 2018].

Larsson, G. (2011), “The return of Ziryab: Yusuf Islam on music”, in T. Bossius, A. Häger and K. Kahn-Harris (Eds.), Religion and Popular Music in Europe: New Expressions of Sacred and Secular Identity (London and New York, NY: I.B. Tauris), Chapter 5, pp. 92-104.

McIver, J. (2014), Bible of Butchery: Cannibal Corpse: The Official Biography (Los Angeles, CA: Metal Blade Records).

Moberg, M. (2011), "Christian metal in Finland: Institutional religion and popular music in the midst of religious change", in T. Bossius, A. Häger and K. Kahn-Harris (Eds.), Religion and Popular Music in Europe: New Expressions of Sacred and Secular Identity (London and New York, NY: I.B. Tauris), Chapter 2, pp. 31-50.

Moberg, M. (2012), "Religion in popular music or popular music as religion? A critical review of scholarly writing on the place of religion in metal music and culture", Popular Music and Society, Vol. 35, No. 1, pp. 113-130.

Mørk, G. (2011), “Why didn’t the churches begin to burn a thousand years earlier?” in T. Bossius, A. Häger and K. Kahn-Harris (Eds.), Religion and Popular Music in Europe: New Expressions of Sacred and Secular Identity (London and New York, NY: I.B. Tauris), Chapter 7, pp. 124-144.

Molinero, S. (2011), "The meanings of the religious talk in French rap music”, in T. Bossius, A. Häger and K. Kahn-Harris (Eds.), Religion and Popular Music in Europe: New Expressions of Sacred and Secular Identity (London and New York, NY: I.B. Tauris), Chapter 6, pp. 105-123.

Moynihan, M. and Søderlind, D. (2003), Lords of Chaos: The Bloody Rise of the Satanic Metal Underground, Revised and expanded edition (Venice, CA: Feral House).

Mudrian, A. (2009), “The making of Darkthrone's Transilvanian Hunger”, in A. Mudrian (Ed.), Precious Metal: 25 Extreme Metal Masterpieces (Philadelphia, PA: De Capo Press), Chapter 14, pp. 179-195.

Olson, B.H. (2008), I am the Black Wizards: Multiplicity, Mysticism and Identity in Black Metal Music and Culture, unpublished Master of Arts thesis, Bowling Green State University, Bowling Green, Ohio, May 2008, available online at: 
https://etd.ohiolink.edu/!etd.send_file?accession=bgsu1206132032\&disposition=inline [accessed 12 February 2018].

Phillipov, M. (2006), “'None so vile?’ Towards an ethics of death metal”, Southern Review, Vol. 38, No. 2, pp. 74-85.

Phillipov, M. (2011), "Extreme music for extreme people? Norwegian black metal and transcendent violence”, Popular Music History, Vol. 6, Nos. 1-2, pp. 150-163.

Prasetyo, F.A. (2017), "Punk and the city: A history of punk in Bandung”, Punk \& PostPunk, Vol. 6, No. 2, pp. 189-211.

Purcell, N.J. (2003), Death Metal Music - The Passion and Politics of a Sub-culture (Jefferson, NC and London: McFarland \& Company).

Resborn, L. and Resborn, J. (2012), Labour of Love \& Hate: An Underground Musical Journey through Southeast Asia (Malmo, Sweden: Bullseye).

Robbins, J.W. (2014), "Louis Armstrong: A rhapsody on repetition and time", in M. Grimshaw (Ed.), The Counter-narratives of Radical Theology and Popular Music: Songs of Fear and Trembling (New York, NY: Palgrave Macmillan), Chapter 7, pp. 8194.

Saefullah, H. (2017), “'Nevermind the jahiliyyah, here's the hijrahs': Punk and the religious turn in the contemporary Indonesian underground scene”, Punk \& Post-Punk, Vol. 6, No. 2, pp. 263-289.

Thornton, S. (1995), Club Cultures: Music, Media and Sub-cultural Capital (Cambridge: Polity Press).

Van Zanten W. (2007), "God is not only in the Holy Scriptures but also in the arts: Music, cultural policies and Islam in West Java, Indonesia”, paper presented at Conference on Music in the World of Islam, Assilah, Morocco, 8-13 August, 2007, available online at: https://s3.amazonaws.com/academia.edu.documents/33434174/van_zanten2007.pdf?AWSAccessKeyId=AKIAIWOWYYGZ2Y53UL3A\&Expires=1518108098 \&Signature $=$ dNT3ItMUUtxY0iW6RWtzTQvLpso\%3D\&response-contentdisposition=inline\%3B\%20filename\%3DGod_is_not_only_in_the_holy_scriptures.pdf [accessed 8 February 2018].

Wallach, J. (2008), Modern Noise, Fluid Genres: Popular Music in Indonesia, 1997-2001 (Madison, WI: University of Wisconsin Press).

Wallach, J. (2011), “Unleashed in the east: Metal music, masculinity, and 'Malayness' in Indonesia, Malaysia, and Singapore”, in J. Wallach, H.M. Berger and P.D. Greene (Eds.), Metal Rules the Globe: Heavy Metal Music around the World (Durham, NC and London: Duke University Press), Chapter 4, pp. 86-105.

Wallach, J., Berger, H.M. and Greene, P.D. (2011), "Affective overdrive, scene dynamics, and identity in the global metal scene”, in J. Wallach, H.M. Berger and P.D. Greene (Eds.), Metal Rules the Globe: Heavy Metal Music around the World (Durham, NC and London: Duke University Press), Chapter 1, pp. 3-33.

Weinstein, D. (2000), Heavy Metal: the Music and its Culture, revised edition (Boulder, CO: Da Capo).

Weinstein, D. (2011), “The globalization of metal”, in J. Wallach, H.M. Berger and P.D. Greene (Eds.), Metal Rules the Globe: Heavy Metal Music around the World (Durham, NC and London: Duke University Press), Chapter 2, pp. 34-59.

Yani, A.R. (2016), Melawan Arus: Membedah Pemikiran Subkultur Punk Islam di Indonesia (Waru-Sidoarjo: Kanzun Books). 
